\title{
Mundo desencantado: o ethos pós-religioso do homem contemporâneo à luz do pensamento de Marcel Gauchet
}

\author{
Disenchanted world: the ethos post-religious of contemporary man \\ in the light of the Marcel Gauchet's thought
}

Fabiano Victor Campos*

\begin{abstract}
Resumo
Este artigo analisa o sentido da expressão "desencantamento do mundo" no pensamento do filósofo francês Marcel Gauchet. Para tal, busca mostrar que, por meio da tese de uma saída da religião, Gauchet apresenta o desenvolvimento histórico da religião em três etapas distintas, porém sucessivas e interligadas entre si, a saber: a religião do passado enquanto configuradora da experiência originária da heteronomia na sua forma mais absoluta, própria das sociedades ditas primitivas ou sem escrita; o momento histórico de saída da religião enquanto evento de absoluta transição da hegemonia heteronômica à hegemonia da autonomia; e, enfim, a etapa atual enquanto momento "pós-religião", no qual se assiste a uma metamorfose da religião em crença pessoal e, assim, a uma transformação da figura do Além ou suprassensível, o que acarreta, por sua vez, diferentes concepções e figuras da transcendência no mundo contemporâneo. Ao percorrer o pensamento gauchetiano em seu arco histórico-analítico, o artigo mostra de que maneira o pensador francês reflete sobre as condições de possibilidade do religioso e da religiosidade nos tempos atuais.
\end{abstract}

Palavras-chave: Desencantamento do mundo; Religião; Religiosidade; Autonomia; Heteronomia.

\begin{abstract}
This article analyzes the meaning of the expression "disenchantment of the world" in the French philosopher Marcel Gauchet's thought. In order to do so, it seeks to show that, through the thesis of an exit of religion, Gauchet presents the historical development of religion in three distinct stages but successive and interrelated each other, that is to say: The religion of the past as the configurator of the original experience of heteronomy in its most absolute form of the so-called primitive societies or without writing; The historic moment of exit from religion as an event of absolute transition from heteronomous hegemony to autonomy hegemony; and, , finally, the current stage as a "post-religion" moment, in which a metamorphosis of religion is seen in personal belief and, thus, to a transformation of the figure of the Beyond or suprasensible, which entails, in turn, different conceptions and figures of transcendence in the contemporary world. In traversing the Gauchetian thought in its historical-analytical arc, the article shows how the French thinker reflects on the conditions of possibility of the religious and religiosity in the present times.
\end{abstract}

Keywords: Disenchantment of the world; Religion; Religiosity; autonomy; Heteronomy.

\footnotetext{
Artigo submetido em 24 de abril de 2017 e aprovado em 13 de junho de 2017.

* Doutor e mestre em Ciências da Religião, com concentração em Filosofia da Religião, pela UFJF. Possui especialização em Temas Filosóficos pela UFMG e graduação em Filosofia pela PUC Minas. Atualmente, é professor do curso de Pós-Graduação em Ciências da Religião do Instituto Santo Tomás de Aquino, em Belo Horizonte. País de Origem: Brasil. E-mail: fvocampos@hotmail.com
} 


\section{Introdução}

Os tempos contemporâneos constituem o palco de um cenário religioso que parece apresentar significativas diferenças em relação à outrora. Fala-se num progressivo enfraquecimento das formas institucionais da religião ou numa espécie de "desregulação institucional das religiosidades" (HERVIEU-LÉGER, 20o8, p. 25). Sustenta-se que a religiosidade passou a se referir muito mais às opções espirituais individuais e pluriformes dos indivíduos do que à conformidade com as tradições religiosas, isto é, com as religiões enquanto instituições capazes de guarnecerem a existência humana de um sentido último ${ }^{1}$. Com frequência, ventilam-se expressões como "religiosidade flutuante" ou à la carte, "religiosidade secular" e plurívoca, vinculadas ao enfraquecimento institucional das igrejas tradicionais, bem como à emergência e ao florescimento de um momento por alguns considerado como pós-metafísico ou pós-religioso.

De fato, dentre os que se esforçam por interpretar tal realidade e pensar as condições de possibilidade do religioso e da religiosidade nos tempos atuais, destaca-se o pensamento do filósofo francês Marcel Gauchet. Sua perspectiva de análise acerca do que entende ser as metamorfoses pelas quais atravessa a cultura contemporânea, assim como as transformações das formas políticas e sociais do estabelecimento humano, que abalam as estruturas individuais e coletivas da consciência, nos impõe profundas interrogações sobre esse processo de reinvenção atravessado pela humanidade e que atinge inclusive a dimensão religiosa. Neste cenário em que vivemos, haverá, pois, um novo modo de ser religioso? Em que consistirá a sua novidade? E qual a relação que ele guarda com os outros momentos da história humana? Eis os questionamentos sobre os quais o pensamento de Gauchet se debruça. Sua tese da "saída da religião”, também nomeada sob o signo

\footnotetext{
${ }^{1}$ Analisando as transformações do catolicismo francês, Hervieu-Léger (1992, p. 195) entende que vivemos uma passagem de uma religião vivida como experiência totalizadora da existência - ou seja, vivida cotidianamente e inserida no curso normal das relações sociais e interindividuais, a religião de uma memória que já não informa o cotidiano dos indivíduos - em direção a uma religiosidade festiva, fundada na associação voluntária, no ajuntamento temporário mobilizado pelo extraordinário e excepcional e na participação móvel, sem vínculos institucionais ou adesão total.
} 
de "desencantamento do mundo", ergue-se como a chave hermenêutica com a qual esse filósofo procura dar uma resposta a tais questões.

Mediante a expressão desencantamento do mundo, terminologia essa que Gauchet retoma de Max Weber² e com a qual intitula uma de suas obras mais importantes, originalmente publicada em 1985, o pensador francês delineia o desenvolvimento histórico da religião em três etapas distintas, porém sucessivas e intimamente interligadas entre si. A primeira delas é a da religião das chamadas sociedades primitivas, isto é, a religião do passado que, segundo Gauchet, configura a experiência originária de uma ordem heteronômica na sua forma mais absoluta. Trata-se da religião própria das sociedades sem escrita, nas quais o fundamento organizacional da realidade social ou coletiva é experimentado na alteridade de sua integralidade, absolutez e intocabilidade. A segunda etapa corresponde propriamente ao que Gauchet denomina de "a saída da religião" ou “desencantamento do mundo". Ela remete ao processo vivenciado ao longo dos últimos dois séculos e meio, mas cujas raízes remontam à pólis grega e, sobretudo, ao próprio advento do cristianismo enquanto religião da saída da religião. Neste momento, assiste-se a uma verdadeira passagem de uma ordem hegemonicamente heteronômica ao seu exato reverso dialético, isto é, a uma ordem absolutamente autonômica. Para Gauchet, tal processo permite o surgimento de sociedades nas quais o fundamento do modo de estruturação do coletivo separa-se, em definitivo, de uma matriz de origem religiosa. Desta sorte, tais sociedades não mais se organizam, tais como as sociedades primitivas, sob o signo de uma dependência em relação ao invisível e ao sobrenatural. A última etapa, enfim, é propriamente a que vivemos e é entendida como um momento “pós-religião”, no qual se vislumbra uma verdadeira transmutação da religião em crença pessoal e, por conseguinte, a uma metamorfose da dimensão suprassensível ou metafísica, o que acarreta, por sua vez, diferentes figuras e concepções da transcendência. Desta sorte, é com base na

\footnotetext{
${ }^{2}$ Não obstante o título de a obra gauchetiana ecoar um tema caro a Max Weber, Willaime (1986) ressente o fato de Marcel Gauchet praticamente não se valer dos trabalhos dos sociólogos. Sobre a trajetória semântica da expressão "desencantamento (Entzauberung) do mundo" no âmbito do pensamento weberiano, ver Pierucci (2003).
} 
relação entrevista entre a religião e o social que Gauchet estabelece as fronteiras que separam a antiga época religiosa, entendida sob o signo de um encantamento do mundo, do atual momento que esse autor propõe chamar de saída da religião.

Neste artigo, procuramos percorrer os aspectos fundamentais de cada uma dessas etapas. Procuramos traçar o arco lógico do pensamento de Marcel Gauchet, percorrendo-o em suas linhas fundamentais, isto é, partindo da análise da relação entre religião e política nas sociedades ditas primitivas, passando pela emergência do Estado e do período axial, para desembocar, enfim, na reflexão acerca da metamorfose engendrada pelo cristianismo enquanto religião da "saída da religião”. Tal percurso nos permitirá dilucidar o significado preciso atribuído às sinonímicas expressões "desencantamento do mundo", "mundo desencantado" e "saída da religião", no bojo do modo gauchetiano de pensar.

De antemão, convém esclarecer que nosso propósito tem um caráter eminentemente didático. Em que pese certo esquematismo de nossa parte, procuramos sintetizar as grandes linhas da metanarrativa gauchetiana do desenvolvimento temporal e histórico do religioso, indo da hegemonia da heteronomia (economia do uno), passando pela máxima autonomia (economia da dualidade) e culminando na perda de força institucional do religioso num contexto que, por essa razão, é denominado de pós-religioso. Entretanto, a princípio, pode parecer aos olhos do leitor atento que a linearidade das três etapas da marcha do religioso, tais como aqui são descritas, sugira uma visão etnocêntrica por parte de Gauchet, baseada na ênfase da inversão ocidental e cristã entre as ordens do além e do humano. Mas, definitivamente, não consideramos ser essa a posição do filósofo francês. Sendo assim, o esquematismo de nosso texto terá em vista tão somente alcançar uma maneira mais didática de apresentar as ideias mestras do pensamento gauchetiano. 


\section{A ordem heteronômica: religião e política nas sociedades primitivas}

Gauchet postula um estado ideal, puro3 e completo da religião, que seria absolutamente característico das sociedades ditas primitivas. A seus olhos, essas sociedades teriam sido totalmente estruturadas pelo religioso 4 na medida em que compreenderam a própria dinâmica organizacional sob a lógica de uma dependência em relação a uma origem mítica inacessível ao homem.

Aqui, o ponto nodal é o fato de o homem pensar a si mesmo na dependência dessas forças invisíveis que ele sacraliza, de se imaginar inteiramente determinado, principalmente no que se refere ao seu ser social, pelos poderes que coloca num plano superior, situando-os acima e como que separados de si próprio. Ele se concebe dependente justamente por se reconhecer impotente para dominar a ordem geral das coisas e as razões de ser da sua sociedade.

\footnotetext{
${ }^{3} \mathrm{~A}$ ideia de um momento puro da religião é um construto, um tipo ideal formulado a partir de fatos empíricos, para diferenciar a forma que o religioso assumiu no passado daquela que ele assume hoje. Neste sentido, a religião em estado puro separa o tempo em atual e original, situando o presente em absoluta dependência em relação ao momento da origem, o qual se esconde num passado impenetrável pelo homem ao mesmo tempo que é constantemente celebrado e repetido através do rito. Além disso, a religião em seu estado primevo e puro é a decisão de fundir-se com a natureza, de realizar uma "inclusão cosmobiológica", isto é, uma "integração carnal aos ciclos do céu e à permanência organizada dos elementos e das espécies", ou ainda, de neutralizar o "antagonismo potencial alojado na relação do homem com a natureza, pela substituição de uma postura constituinte de confrontação por uma postura simbólica de pertença" (GAUCHET, 1985, p. 17). A concepção dos gregos antigos do mundo como cosmo, isto é, como um universo ordenado por esferas concêntricas e cuja ordem o microcosmo humano deveria espelhar, insere-se no plano dessa escolha religiosa a que Gauchet se refere. Sobre o cosmologismo grego, cf. Vaz (2001, p. 172-187).

${ }^{4}$ Sabe-se que a história das crenças por vezes foi compreendida desde o ângulo do progresso na racionalização dos dogmas e do avanço em relação à concepção do divino, da qual o monoteísmo constituiria sua noção mais elaborada. Ao passo que o estado puro, mais sistemático e completo da religião, é situado na origem, ou seja, nas formas religiosas das sociedades primitivas, e não nas religiões universais, que são apenas etapas de seu relaxamento. Nesse sentido, Gauchet inverte a perspectiva evolucionista da religião. Pierre Manent (1986) e Jean-Paul Willaime (1986) insurgem-se contra essa tese gauchetiana. Questionando a pertinência e o sentido do conceito gauchetiano de "religião mais religiosa", ou de "religião por excelência", Manent entende que não seja uma noção perfeitamente clara. Além disso, questiona a razão pela qual se deve aplicar essa ideia à religião primitiva, e não às religiões da transcendência e, nesse sentido, se pergunta que estatuto o cristianismo precisamente adquire no âmbito do pensamento gauchetiano. Por outro lado, também questiona se a aproximação em termos de heteronomia e de alteridade basta para diferenciar as diversas religiões, entendendo, pois, que o Deus judeu ou cristão não é apenas o Outro, mas é qualificado também por um certo número de atributos. Já Willaime (1986) critica o fato de Gauchet partir de uma essência do religioso. Para esse autor, "partir de uma tal definição da essência do religioso nos parece eminentemente contestável, pois é, de início, se colocar em um ponto de vista que avaliará a evolução religiosa à luz dessa definição" (WILLAIME, 1986, p. 69). Por outro lado, afirma ser dificilmente aceitável a definição de religião estabelecida por Gauchet. Para ele, "as formas do religioso não são imutáveis e não há nenhuma razão para pensar que as evoluções representam uma degradação em relação a formas julgadas mais puras do religioso" (WILLAIME, 1986, p. 70). Neste sentido, adverte ainda o crítico, "admitir essa concepção da essência do religioso é, de início, interpretar a autonomização crescente do homem e da sociedade em relação ao mundo dos deuses como uma marcha fora da religião, como se não pudesse existir uma religião que preconizasse a liberdade do homem e a autonomia de seus empreendimentos" (WILLAIME, 1986, p. 70). É contra essa ideia de essência do religioso que ainda se dirige a crítica de Paul Valadier (2004), para quem o pensamento de Gauchet, ao propor uma lógica histórica que teria sua origem desde as eras primitivas, ergue-se sobre os postulados da identidade. De modo diverso, Emmanuel Terray (1991, p. 114-124) chega à mesma conclusão que Paul Valadier.
}

Horizonte, Belo Horizonte, v. 15, n. 46, p. 376-411, abr./jun. 2017 - ISSN 2175-5841 
Mas por que razões os homens optaram por estabelecer tal separação, entendendo-se numa dependência completa em relação à realidade situada para além de suas capacidades? Trata-se, segundo o autor, de uma "opção intelectual”, um "preconceito metódico do pensamento", de uma "decisão tomada pela sociedade”, de uma "posição sistemática adotada consciente ou inconscientemente" (GAUCHET, 1977, p. 64-65). Gauchet constata que não há nenhum dado objetivo que pudesse provocá-la de modo linear ou mecânico. Sua intuição original é de que essa decisão religiosa de estabelecer a separação entre duas esferas de realidade deriva de um "desígnio interior ao espaço social”, a saber, "a finalidade de impedir que quem quer que seja dentre os homens possa falar em nome da legitimidade última da coisa coletiva e a partir do lugar da origem - quer dizer, exercer o poder" (GAUCHET, 1977, p. 66). O que o dispositivo religioso das sociedades primitivas pretende evitar é o apossamento do poder através duma participação da esfera divina, ou seja, que alguns dentre os homens venham a se outorgar o direito de representar os seres do Além e falar não do lado da Lei sagrada, mas em nome dela. A obediência à Lei se dá não por imposição, mas por uma dinâmica de despossessão que, embora não impeça o jogo das diferenças sociais de status ou prestígio, funciona como um profícuo instrumento capaz de assegurar a igualdade política e evitar a cisão de um poder. “Todo o dispositivo social é organizado de forma a excluir a passagem de um entre os homens para o lado da verdade do fundamento, e, por conseguinte, do poder" (GAUCHET, 1977, p. 78). Assim, o chefe primitivo, tal como os outros, tem de se conformar com uma norma e uma vontade absolutas, sobre as quais ninguém exerce qualquer domínio. O papel exercido em função do seu status de chefe se limita à celebração da sabedoria dos ancestrais, cuja vontade e grandes feitos devem ser constantemente recordados e repetidos através dos ritos. Portanto, a função política das concepções religiosas é fazer com que "o exercício do poder sobre a ordem das coisas, a começar pela ordem das coisas humanas, dimane de outros que não dos homens" (GAUCHET, 1977, p. 81).

Mas a exterioridade do fundamento, na qual os seres invisíveis têm lugar, não é suficiente para que se mostre inconcebível a priori o acesso de um homem 
para o lado do poder criador das origens, para que seja invalidada de início toda pretensão de se pensar ou de se falar do lugar do absoluto divino no espaço humano, enfim, para que seja impossível aos humanos identificarem-se com a visão do outro situado algures. Daí ser indispensável a separação temporal do fundamento, que resulta de sua designação a um passado primordial. Noutros termos, a necessidade de representação da origem numa temporalidade radicalmente diferente, de modo que ela não seja "simples tempo antigo no prolongamento do qual se situaria o presente social", mas "um tempo em que sucedeu qualquer coisa que não tem lugar no tempo atual dos homens, a saber, uma instauração" (GAUCHET, 1977, p. 79). Trata-se da divisão entre um passadofonte e um presente-cópia destinado a perpetuar, por meio de rituais, aquele acontecimento fundante. $\mathrm{O}$ rito possibilita o retorno permanente ao momento sagrado das origens. Viabilizando o acesso ao tempo inaugural, o rito restaura e faz emergir novamente o mundo dos presentes-vivos que, paradoxalmente, já havia sido instaurado de uma vez por todas. Assim, em virtude de sua própria extremidade, a distância se transforma em proximidade, a ausência em presença, a divisão em fusão. O presente é, pois, subordinado ao passado puro, o atual encontra no original a sua razão de ser. A preponderância absoluta do passado mítico é um meio profícuo de estabelecer um corte entre o instituinte e o instituído, ou seja, é um recurso eficaz para fundar uma ordem integralmente recebida, totalmente subtraída à influência da ação humana.

Todavia, convém observar que o referido tempo das origens não deve ser concebido como um momento de criação ex nihilo por parte das divindades que povoam os panteões. Os começos, os acontecimentos e as instaurações parciais e sucessivas são concebidos como obra da contingência - portanto, possuem um caráter acidental - ou então referidos mais à ação dos heróis ancestrais que à vontade dos deuses. Estes, por sua vez, nada instauram e nem regem o curso do mundo no qual se inscrevem. Paradoxalmente, é a redução do poder divino que inviabiliza a influência humana sobre a intenção criadora responsável pela existência das coisas tais como são. 
Observa-se, pois, que as sociedades primitivas não ignoram e nem eliminam o problema do poder, mas se organizam de modo a contê-lo e a dominá-lo. A tentativa de impedir a cisão entre senhores e súditos na esfera empírica repousa sobre o fato de que tal separação existe em estado virtual, de modo que penetra invisivelmente a sociedade e a domina na sua organização (GAUCHET, 1977, p. 72). De fato, a questão do poder se impõe na dinâmica da antropogênese, isto é, na própria gênese do homem. O poder não é abolido ou aniquilado, mas permanece sob a forma de um aparente finalismo, isto é, enquanto virtualidade estrutural que a sociedade carrega em si mesma. Não se trata de ver o poder como uma possibilidade conjectural extrínseca à sociedade. Ao contrário, a própria condição de possibilidade do social é a presença desta articulação originária, deste dado interno inicialmente presente, mas constantemente recalcitrado. Numa terminologia aristotélica, significa dizer que a separação, entre os homens, de uma autoridade que confira legitimidade ao poder e que venha a impô-lo de modo coercitivo, não existe enquanto ato, mas senão em potência. De fato, "não existe Estado nas sociedades primitivas. Mas existe a sua possibilidade que a sociedade se esforça, precisamente, por afastar. [...] Onde não existe Estado, existe apesar de tudo, repelido ou contido, o princípio de origem do Estado, a saber, a constituição primordial de todo o espaço social na e pela divisão política” (GAUCHET, 1977, p. 73)5. Neste sentido, a história humana é tão somente, como sublinha Gauchet, uma luta longamente vitoriosa contra a alienação política, isto é, contra a separação de uma instância do poder.

A condição de possibilidade da associação humana, assim como do pensamento religioso, é esse desapossamento completo, radical e metódico da sociedade com relação ao seu próprio sentido, de modo que ela situa fora dela o lugar a partir do qual se pretende ordenável e inteligível. É neste sentido que

\footnotetext{
${ }^{5}$ Convém notar que o autor em foco caminha na esteira do pensamento de Pierre Clastres (1974), o qual preconiza a tese da sociedade contra o Estado; a propósito, ver Gauchet (1977, p. 72; 1985, p. 16). Em A sociedade contra o Estado, Pierre Clastres procura mostrar como as sociedades se organizam no sentido de impedirem a concentração do poder nas mãos de um ou de mais indivíduos, isto é, no sentido de inviabilizarem a instauração do Estado. Sobre as dívidas das teses de Marcel Gauchet em relação à teoria de Pierre Clastres, das quais não temos condições de tratar aqui, dados os limites circunscritos pelo nosso tema, ver sobretudo os estudos de Terray (1991) e de Magnelli (2015).
} 
Gauchet (1977, p. 69) assevera que "o fundamento do Estado é igual ao da religião". Isto significa que a origem das sociedades repousa nessa dinâmica de alienação radical, na qual a sociedade transfere o sentido de seus modos de organização e suas razões de ser a uma dimensão exterior e radicalmente distinta. Nas palavras do autor, “[...] existe uma distância da sociedade em relação a ela mesma, uma ruptura interna do tecido social sem as quais não haveria sociedade. $\mathrm{O}$ elemento constitutivo do social é a sua divisão em relação a ele mesmo" (GAUCHET, 1977, p. 67). Tal separação da sociedade corresponde à “estruturação política originária do fato social”. Neste sentido, as sociedades primitivas não são aquelas concebidas como pré-históricas, destituídas de escrita ou de cultura, e cuja organização social é determinada pela submissão a uma coação exterior. Nelas não há traço de uma inteligência bruta ou espontânea, ou de um entendimento elemental das coisas, isto é, um estado rudimentar ou atrasado de desenvolvimento. Ao contrário, na esteira da interpretação desenvolvida por Gauchet, as sociedades primitivas angariam o status de "sociedades já plenamente civilizadas, que pertencem claramente à mesma história que a nossa e que participam, sem dúvida e nem reserva, do sistema de opções sobre o qual continuamos a viver" (GAUCHET, 1985, p. IX). Mas ao passo que as sociedades hodiernas caminham na esteira da opção religiosa das sociedades primitivas, escolha esta que as aproxima e lhes confere uma identidade entre si -, a ausência efetiva (mas não virtual!) do Estado no que concerne às sociedades selvagens as distinguem das sociedades ditas modernas. Outra diferença é que nas sociedades primitivas há o primado do todo sobre as partes que o organizam. Trata-se daquilo que Louis Dumont chamou de sociedade "holista", em oposição ao modelo individualista presente em nossas sociedades hodiernas. O modelo holista corresponde ao tempo das sociedades que se articulam em torno à religião. Além disso, as sociedades primitivas estão determinadas, de forma sistemática, pelo imperativo de alteridade da lei instituinte que ordena a economia da indivisão social. Nelas há uma estreita conformidade entre a norma e o ser. E, por fim, diferentemente de nós, os primitivos não compreendem o funcionamento do 
mundo regido pela influência magistral de uma unicidade ou subjetividade reitora. Antes, enxergam-no sob a ótica da multiplicidade, da pluralidade e da diversidade.

Do mesmo modo, a religião deriva dessa cisão constitutiva da sociedade, dessa divisão primeira, anterior à separação do Estado. Dela, o fato religioso é concomitantemente uma expressão e uma neutralização. Expressão porque a dependência religiosa traduz, representando-a, a inferioridade humana sentida frente aos poderes que lhe são infinitamente superiores e distintos. Noutros termos, a religião é a tradução intelectual dessa separação que constitui o social. Ora, é através da religião que se instala uma linha de divisão entre os homens e as modalidades da sua organização em sociedade, é por meio dela que a sociedade se articula com o seu exterior, enfim, é por intermédio da religião que a sociedade separa a realidade em duas dimensões distintas (GAUCHET, 1977, p. 66). E neutralização porque, ao calcar as razões de ser e a ordem da sociedade na dependência em relação a uma entidade diferente da própria sociedade, a religião impede o aparecimento efetivo de um poder separado, ou seja, veda a possibilidade de que alguém venha a sentir-se intimamente autorizado a participar da verdade exterior e, julgando-se representante do invisível, intente impô-la ao resto da sociedade (GAUCHET, 1977, p. 67, 78). O pensamento religioso primitivo explicase por esse imperativo político de indivisão dos homens. Neste sentido, numa entrevista a Esteban Molina, o tradutor espanhol de $O$ desencantamento do mundo, realizada em setembro de 2005, em Paris, Gauchet (2005, p. 294) sublinha que a religião foi, ao princípio e durante milênios, "um ordenamento do mundo humano-social, uma maneira de compreender e de instituir o poder, os vínculos entre os seres, a forma das comunidades”. Sua função social consistia em manter a sociedade em absoluta dependência com relação à ordem estabelecida pela alteridade situada alhures, escondida num passado inacessível, o tempo da instauração atualizado pelos ritos. Por exercer este papel de estruturação primordial do campo coletivo, a religião é considerada pelo autor como uma "peça muito efetiva do dispositivo social, [...] uma peça desempenhando um papel estratégico no funcionamento social real" (GAUCHET, 1977, p. 66). 
Com efeito, Gauchet não ignora nem nega o aspecto fenomênico da religião. Todavia, procura identificar o que constitui a essência da religião, situando-a na operação de "estabelecimento de uma relação de despossessão entre o universo dos viventes-visíveis e seu fundamento" (GAUCHET, 1985, p. 11) ou, mais precisamente, na alienação do homem através da "dívida do sentido"6. Por meio dessa expressão, o autor alude àquilo "que durante milênios os homens reconheceram dever aos deuses, o que as sociedades, mais ou menos desde sempre, acreditaram dever às determinações dos outros, aos decretos do Além ou às vontades do invisível” (GAUCHET, 1977, p. 51). Desta sorte, segundo Gauchet, o religioso consiste numa relação de negatividade do homem social consigo mesmo, é a energia radical de negação que define o humano e que se revelou sob a forma de uma rejeição do homem com relação à sua influência transformadora na organização do seu próprio mundo. Negação que se reverte em benefício da lei estabelecida e a ela reconduz a sociedade. A religião, por sua vez, é a forma institucionalizada - isto é, socialmente traduzida e materializada - do homem contra si mesmo, que o destina irresistivelmente a uma não aceitação transformadora, quer seja em relação à natureza ou à cultura na qual está inserido, quer seja concernente aos seus semelhantes ou a sua própria realidade íntima. Ela procede originariamente de uma livre operação instituinte, resulta de um ato de criação que expressa uma escolha da sociedade, é peça de um dispositivo cuja função foi decidida. É, pois, um produto social que a própria sociedade poderia dispensar, é resultado de uma decisão social que poderia ter sido diferente. Ora, esta escolha humana de possuir-se através do despossuir-se (da alienação), de abrir mão de sua autonomia criativa em função de algo que lhe conferirá uma identidade, é a própria essência da religião. E no que concerne a essa “opção religiosa", o homem caminhou no sentido de uma ordem integralmente sofrida a

\footnotetext{
${ }^{6}$ Olivier Abel (1999, p. 57) se ressente que Gauchet pense a religião apenas sob o signo de uma dívida do sentido. Para esse crítico, há nas religiões, por vezes, algo que não é simplesmente da ordem do endividamento para com os antigos. Para ele, haveria de se atribuir um lugar também àqueles que nascem. Em outros termos, o sentido do nascimento, ou mais exatamente ainda, a possibilidade de todo recomeçar juntos, é presente em muitas figuras religiosas. Abstendo-se, pois, de pôr essa questão, Gauchet não faria jus a toda forma de religião, ou mais precisamente ainda, não manifestaria uma compreensão adequada do religioso. Se a ênfase de Gauchet recai, assim, sobre a dívida para com o passado, caberia questionar se não é preciso distinguir, no âmbito religioso, uma figura de esperança, como Ernst Bloch, para quem a esperança e a promessa também contam.
} 
uma ordem cada vez mais desejada. Pois mesmo naquelas sociedades estruturadas a partir de uma heteronomia, havia uma certa autonomia, uma opção inconsciente: "lá mesmo onde devíamos nos submeter à dominação de nossos semelhantes, fomos reconhecidos como os autores livres e iguais da regra coletiva" (GAUCHET, 1985, p. VI). Nesta dialética constitutiva do homem, a oscilar entre o querer e o sofrer, é que encontramos a chave de toda a história humana.

Todavia, segundo Gauchet, esta situação de absoluta heteronomia, sofrida e desejada pelos homens em sua realidade social, muda radicalmente com a emergência do Estado. Eis o que agora nos cumpre aclarar.

\section{A emergência do Estado à luz do fato religioso}

Para Gauchet (1977, p. 51), “[...] a chave do problema do Estado se deve procurar do lado das raízes profundas do fato religioso". Isso porque o Estado deita as suas raízes naquilo que constitui a forma mais determinante e a razão mais geral da crença religiosa, isto é, a dinâmica simbólico-religiosa que é consubstancial à vida social e que Gauchet denominou como dívida do sentido.

Ora, o surgimento do Estado apresenta uma diferenciação entre os homens sob a lógica da divisão entre dominação e submissão. Tal aparecimento assinala uma relação de sujeição entre indivíduos que passam a se conceberem como sendo de naturezas diferentes, não obstante pertencerem à mesma coletividade. Mas esta distância entre governantes e governados se insere no plano de um prolongamento de uma sujeição anterior e, portanto, mais original, através da qual os homens se afirmaram universalmente devedores, atribuindo as razões de ser e a ordem interna das sociedades à intervenção externa dos senhores do Além. Ou seja, o Estado não passa de uma nova face daquela separação que já penetrava as sociedades primitivas e que é a própria condição de possibilidade desse fato social7.

\footnotetext{
7 O Estado "introduz na sociedade uma separação entre os representantes exclusivos da lei e do saber e a multidão cujo destino é submeter-se. Mas não institui a separação entre a sociedade e os poderes supostos de a compreenderem, de a quererem tal como ela é e de a regerem. Se não tivesse havido esta primeira separação, não teria tido sentido o aparecimento do Estado" (GAUCHET, 1977, p. 68).
} 
Ele funda-se numa dimensão de exterioridade em relação à própria sociedade, isto é, no imperativo para a sociedade de se ler em coisa diferente dela, de conceber o seu significado sob o signo da dívida, ou ainda, na necessidade de heteronomia que persegue a associação dos homens desde o início. Sua emergência é "a primeira revolução religiosa da história” (GAUCHET, 1985, p. XVI), pois representa a interiorização da alteridade que antes governava a relação da sociedade desde um plano exterior. Em seu advento, o Estado, enquanto instância de poder que se separa da sociedade, tomará o lugar outrora ocupado pelos deuses. Isso porque "faz parte da lógica interna do desenvolvimento do poder estatal destruir a referência da sociedade a qualquer coisa que não seja a ele próprio. Enquanto se apresenta como o representante e o agente do poder divino, o poder do Estado esgota-se no desenvolvimento da virtualidade fundamental que transporta e que o constitui”. (GAUCHET, 1977, p. 85). Em sua emergência, o Estado realiza o que outrora era reprimido: a separação do poder ou a divisão entre os homens. A lei fundadora adquire seus representantes, seus administradores e intérpretes no seio da sociedade.

Ao situar a separação do poder estabelecida pelo Estado na linha de continuidade em relação a uma divisão primeira, o autor pretende romper com uma representação positiva e instrumental da divisão social, que a concebe como derivada da necessidade material do desenvolvimento das sociedades num dado momento histórico. Nas palavras do autor,

Antes do Estado, houve somente sociedades da separação, sociedades que buscavam fora delas mesmas o seu princípio fundador, a origem do seu modo de organização, a explicação do seu sentido, a razão das suas regras e dos seus usos. A exterioridade do fundamento social preexiste ao Estado. Ela é fato primeiro na história das sociedades em relação às quais o aparecimento do Estado não passa duma transformação tardia transformação certamente decisiva, mas que de modo algum surgiu do nada. O Estado é inovador na forma claramente aberta que confere à divisão da sociedade, na alteridade que transporta para o interior da comunidade dos homens até levá-los a pensarem-se duma natureza diferente consoante dirigem ou se submetem, introduz um tal corte na maneira como os indivíduos se reconhecem uns aos outros dentro do mesmo espaço que dá a impressão duma invenção sem precedente. [...] 
Todavia, esta alteridade que ele injeta no tecido social não a extrai da sua própria substância. Ela já existia. Somente a faz refluir para dentro da sociedade quando, até então, ela comandava a relação da sociedade do seu exterior. (GAUCHET, 1977, p. 53-54).

Deste modo, a instauração do Estado não corresponde a uma criação social absoluta ou à produção de uma instância social que teria provocado, de modo inédito, a cisão entre dominantes e dominados no seio da sociedade. Noutros termos, o advento de um poder separado da comunidade não significa uma criação ex nihilo na história das sociedades. Todavia, ao fundá-lo sobre a necessidade, o autor não pretende recusar ao Estado o seu aspecto de imprevisibilidade, senão negar que o Estado seja, de algum modo, necessário por ele mesmo.

Ora, dizer que o Estado origina-se duma esfera de exterioridade não significa afirmar que tal exterioridade devesse se desenvolver necessariamente sob a forma de separação do poder. Para Gauchet, os homens poderiam apenas ter concebido as forças invisíveis como hierarquicamente superiores às suas, sem contudo atribuir-lhes um estatuto ontológico diferente. Afinal, superioridade não significa necessariamente alteridade. Por que então considerá-las como portadoras de uma natureza radicalmente distinta em relação à dos homens? A passagem da superioridade hierárquica à diferença ontológica descortina uma decisão, uma deliberação social. Para ter ocorrido, "é necessário que tenha sido socialmente reconhecida e estabelecida uma divisão entre o além e o aquém da capacidade material dos homens, entre esferas absolutamente distintas de eficácia" (GAUCHET, 1977, p. 62). Não é que se trata de dimensões absolutamente separadas e desligadas uma da outra no que concerne à vida social. Antes, os dois domínios interpenetram-se, estão em relação. Porém, o mundo invisível diferenciase daquele na medida em que escapa ao domínio direto dos homens, tanto no plano de sua sensibilidade quanto no domínio de sua inteligibilidade. Desta sorte, a esfera do Além é concebida como que possuindo uma realidade própria, impenetrável aos sentidos humanos, assim como uma lógica própria, inescrutável à capacidade cognitiva do homem (GAUCHET, 1977, p. 83). 
No momento da emergência do Estado, essa fratura religiosa com o Além deixará de ser signo de igualdade entre os homens e virá a justificar a divisão entre os que participam da essência da divindade e, por isso, detêm o poder, e os que juntos formam a massa comum dos que devem inclinar-se a obedecer as determinações dos intermediários do invisível (GAUCHET, 1977, p. 68). É com o advento do cristianismo, todavia, que tal separação entre os homens é sobremaneira internalizada.

\section{0 cristianismo como a religião da saída da religião}

Vimos que a divisão religiosa seguiu perfazendo-se em duas etapas: por primeiro, a da separação entre o ser humano e seu fundamento; em seguida, com a emergência do Estado, ela converte-se em divisão entre os homens. Desse modo, no princípio a separação era exterior ao corpo social; num segundo momento, ela desloca-se para o interior da sociedade. Todavia, Gauchet ainda observa um terceiro momento nessa dinâmica da separação que constitui o social, no qual a cisão constitutiva da sociedade translada-se ao interior dos homens sob a forma de um alter ego, provocando uma fratura no ser. O autor refere-se a esse outro momento como "a possibilidade de descobrir ou de mobilizar um outro si; de passar à posição de estranheza frente a seu próprio si ordinário e, em consequência, face a face à imediata realidade do exterior em que mergulha" (GAUCHET, 1985, p. 47). Do ponto de vista do ator religioso, esta transformação pode ser descrita como um duplo processo: trata-se de uma promoção da interioridade que se desenvolve correlativamente à redução da alteridade divina. Para Gauchet, a emancipação da razão humana frente ao mundo só se torna possível mediante a inversão de perspectiva da transcendência divina realizada pelo cristianismo ${ }^{8}$, que acaba por reduzir a alteridade de Deus.

\footnotetext{
${ }^{8}$ Segundo Gauchet (2004, p. 137-138), não é “o cristianismo em geral que está em causa, mas a variante específica do cristianismo que se define em torno do ano mil e da qual a reforma gregoriana é o aspecto institucional visível. [...] Ela vai conduzir a esta coisa sem precedente que é a aparição de uma sociedade que se organiza fora da dependência religiosa. O poder cessa de ser um poder sagrado que cai do alto. Ele sai da sociedade: é o que nomeamos democracia. O fato central deste percurso é a construção de uma instituição que vai ser a alavanca desta reapropriação: o Estado. [...] A história europeia relançou esta dialética entre política e religião, no interior do cristianismo, até produzir uma política livre da religião".
} 
Para Gauchet, o advento da religião cristã acarreta uma metamorfose da antiga exterioridade religiosa temporal, exterioridade essa que cede lugar à ideia de uma alteridade divina espacial. A divindade passa a ser então compreendida em termos de uma subjetividade que governa o mundo no presente. Ao expurgar a divindade do seio do mundo, o cristianismo produz uma separação espacial entre deus e o mundo dos homens. Mediante tal separação, a divindade é constituída em sujeito absoluto do mundo. Mas a transcendência de Deus concebida na perspectiva espacial dos cristãos não possui a mesma força de exterioridade que havia na transcendência divina sob a ótica temporal das sociedades primitivas. Nesta última, a alteridade do invisível instituinte se mantinha absoluta, ao passo que naquela outra perspectiva ela se apresenta relativa. Isto porque o entendimento humano, por si só, é agora capaz de perscrutar as intenções divinas. A razão humana não mais precisará da iluminação proveniente do intelecto divino para chegar ao conhecimento da verdade. A intelecção do mundo se dá independentemente do auxílio de Deus. Com efeito, o aumento do poder dos deuses significará atribuir-lhes a invenção do mundo, conferindo aos homens a possibilidade de acesso às razões da origem e a consequente diminuição da sujeição destes últimos ante àqueles. Nas palavras do autor, “[...] o mais de alteridade figurada ou vivida corresponde a um menos de alteridade efetivamente praticada, [...] alguma coisa como uma lei da emancipação humana pela afirmação divina [...]. Em realidade, a imanência supõe a cisão irremediável com o fundamento; ao passo que a transcendência o aproxima e o torna acessível.” (GAUCHET, 1985, p. 53-54). Portanto, é a ideia de criação que introduz acessibilidade ao fundamento. Paradoxalmente, a separação da divindade em relação ao mundo a torna mais acessível, pois não mais se esconde num passado imemorial. De certo modo, a divindade torna-se presente, pois é uma divindade interior com a qual é possível comunicar-se e mesmo estabelecer uma relação íntima de comunhão, e cuja sabedoria e intenções são passíveis de serem penetradas, decifradas e provadas na própria interioridade humana. O sentido deixa de ser simplesmente dado ou recebido e converte-se em sentido querido e perscrutado. E uma vez que se abre ao homem a possibilidade de perscrutar em si mesmo as intenções divinas, ele toma 
posse de seu fundamento religioso. Se antes havia uma despossessão radical dos homens acerca da fonte do sentido e do foco da lei, agora há uma reapropriação daquilo que foi inicialmente rejeitado e radicalmente posto fora do alcance dos atores humanos. De posse do seu próprio destino e encontrando suas razões de ser senão em si mesma, a sociedade liberta-se da alienação religiosa.

O surgimento do Deus cristão enquanto ser universal e separado do mundo implica a inversão radical da organização religiosa: de uma economia do uno, que fusiona o visível e o invisível, a uma economia da dualidade, que dissocia as duas esferas. Trata-se de uma nova articulação do visível e do invisível pressuposta pela figura cristã do divino que, segundo Gauchet, se constitui como a expressão estruturalmente mais acabada da grande inversão espiritual do "período axial”. O surgimento da transcendência reunifica o original e o atual, (reabsorção do tempo da criação no presente divino) modificando completamente a natureza do poder sobrenatural, que passa a ser, a um só tempo, a fonte e o responsável pela marcha do mundo. Sua emergência fusiona o que estava separado, o original e o atual, e distingue o que estava mesclado, o natural e o sobrenatural (separação do fundamento). Translada-se de uma experiência da proximidade a uma experiência da diferença, de um sistema de copertencimento com uma multiplicidade de deuses a um sistema de separação em relação a um único princípio divino. Ora, nas duas primeiras etapas da divisão religiosa constitutiva da sociedade, o visível e o invisível se tocam, acoplam-se em uma única e idêntica realidade. Os homens vivem sob o regime do inquestionável instituído. Já na terceira etapa ocorre uma reordenação desta articulação entre o visível instituído e o invisível instituinte: o que outrora era conjunção agora se torna disjunção, diferenciação organizadora entre o mundo humano e a esfera do além. A sociedade se encontra agora sob o regime do questionável virtual.

Com efeito, no momento em que se desfaz a conjunção entre o visível instituído e o invisível instituinte, torna-se problemático todo o sistema de relações entre as duas ordens de realidade. A questão que se imporá permanentemente é: 
“que vale este mundo comparado com seu Outro?” Os diferentes tipos de resposta, por sua vez, oscilam entre o individualismo ascético e o holismo integrador, isto é, enquadram-se em dois polos extremos: por um lado, a gnóstica desvalorização deste mundo em benefício do outro, por vezes traduzida na supremacia da importância atribuída à alma em relação ao seu cárcere corpóreo; por outro lado, a teocrática tentativa de reconciliação entre as duas esferas, cuja meta é superar esta experiência de dualidade remontando-se até à impessoal unidade do nada primordial. O paradoxo observado é que no seio do universo concebido como uno (universo primitivo), o pensamento respondia a uma lógica do múltiplo, ao passo que em um mundo dual emerge um pensamento governado pelo enfoque do uno.

O que Gauchet observa é que a transcendência do Deus cristão elevou o princípio metafísico da autonomia humana ao seu apogeu9. Isso porque, com a emergência e a radicação da religião cristã, instaura-se uma metamorfose do outro mundo e, correlativamente, uma remodelação do ser-neste-mundo, desde a maneira abstrata de compreendê-lo à forma material de habitá-lo, isto é, de coexistir com ele.

Com efeito, aos olhos gauchetianos, a nova representação do divino acarreta uma liberação intelectual e política: da absoluta submissão a uma ordem integral e recebida do além, o homem é remetido à possibilidade de comunicação e negociação com um "deus-sujeito que governa o mundo no presente" (GAUCHET, 1985, p. XV). Noutros termos, é anulada qualquer dependência expressa ou direta deste mundo com relação ao além. A separação de Deus com relação ao mundo em um só golpe instaura a objetividade do mundo e faz emergir o sujeito puro, ou seja, ela desencadeia o longo processo de cisão entre sujeito e objeto, que no racionalismo de inspiração cartesiana adquire contornos paradigmáticos - pois em

\footnotetext{
${ }^{9}$ Neste sentido, conviria questionar se não é possível pensar, com base no pensamento de Gauchet, uma espécie de duplicabilidade da transcendência, ou seja, se a partir dessa transcendência absoluta do Além é que se instaura a transcendência copernicana do humano ante a natureza. Evidentemente, seria preciso aí questionar até que ponto essa última transcendência não é senão uma das formas de realização da imanência da razão humana, desde então destinada a se dirigir ao mundo dos fenômenos. Trata-se, pois, de um paradoxo de intensa potencialidade conceitual e que deveria ser considerado pelo círculo dos bem-pensantes, sobretudo aqueles que procuram investigar as implicações do pensamento gauchetiano.
} 
Descartes, para além da distinção, instaura-se uma dicotomia entre as duas instâncias. Ora, o desdobramento completo da transcendência até à perfeição de um deus-sujeito separado da esfera visível desencadeia uma revolução teórica da objetividade do mundo. Surge uma concepção laica da natureza do mundo, que passa a ser concebido em termos de objetividade global e de necessidade interna. Deus é o grande relojoeiro que, depois de criar o melhor dos mundos possíveis, dele se afasta, entregando-o ao automatismo de suas leis naturais. Correlativamente à instauração da objetividade do mundo, emerge o sujeito puro ou transcendental, o sujeito do conhecimento. Assim, ao passo que vai se desdobrando o processo de transcendentalização divina até a completa representação de um deus-sujeito fora do mundo, a razão humana vai adquirindo uma autonomia singular e sem precedentes. Mais ainda, o próprio nascimento daquilo a que chamamos de racionalidade depende dessa forma determinada de subjetivação e de separação do Outro que faz ser, isto é, do Deus criador. A concepção cristã da transcendência divina acarreta, por conseguinte, uma espécie de transcendência ativa do homem sobre a natureza, de modo que este se eleva à posição de sujeito puro do conhecimento. Noutros termos, a grandeza de Deus elevando-se a seu grau supremo move e reflete os progressos da racionalidade do homem, determinando sua autonomia enquanto sujeito do conhecimento. Duplo processo de desenvolvimento do absoluto divino e, correlativamente, de afirmação dos poderes do intelecto humano. De uma inserção espontânea nos ritmos naturais do mundo e da aceitação em habitar o espaço hermético de seus ciclos, o homem passa à posição de manipulador dos fenômenos e criador do universo das leis. É estabelecida uma transcendência ativa do homem com relação ao mundo outrora representativamente dado, mas que agora passa a ser construído - aliás, não será esta a grande revolução copernicana identificada por Kant? Desta sorte, para Gauchet, essa transformação da posição do homem frente à natureza finca suas raízes no processo de transcendentalização de Deus, que se consuma na sua separação absoluta do mundo. 
Por fim, o referido desenvolvimento da transcendência divina implicará uma revolução prática da autonomia da dimensão humano-social e uma concepção laica da natureza do vínculo social. A exterioridade, que outrora governava as sociedades a partir de outro lugar, transcendente e inacessível, é agora subsumida no interior do espaço coletivo. Assim, "o deus que cessa de estar presente na natureza não deixa menos de manifestar-se tangivelmente nas hierarquias que organizam o vínculo coletivo" (GAUCHET, 1985, p. 64). Emerge o Estado, significando a independência ontológica do corpo político e o poder de dar-se a lei a si mesmo. E inverte-se o papel do soberano: de mediador que liga a terra ao céu, de conjunção personificada da ordem visível com seu fundamento invisível, passa a atestar a separação entre as duas dimensões; já não corporifica a presença do invisível, mas testemunha sua ausência. $\mathrm{O}$ fundamento e o destino do vínculo social não mais se referem à ação de uma força exógena à própria sociedade, mas se encontram assentados na própria ação dos homens. No domínio teórico, esta forma de compreender a realidade político-social se expressará sob a forma de uma teoria do contrato social propugnada por pensadores políticos dos séculos XVII e XVIII, segundo a qual o poder de todos é recolhido e refletido no poder do governante soberano. Observa-se, portanto, que a restituição do vínculo social ao poder dos homens é, no fundo, religiosa, no sentido de que o desenvolvimento da transcendência divina até o seu acabamento em termos de uma subjetividade fora do mundo provoca a redução da alteridade, viabilizando aos atores humanos o controle de seu destino coletivo. Já no domínio prático, trata-se da separação estabelecida entre Estado e religião, de forma que a religião permanecerá restrita à 
esfera da sociedade civilio.

Segundo Gauchet, a inversão da relação da figura do Além com o humano é atestada tanto pela ideia de criação quanto pela noção de revelação, tais como emergem no cristianismo. Na ideia de criação culmina a compenetração do passado (princípio original) e do presente (atual governo do real). Ela é o acabamento final do processo de cristalização da transcendência. Consuma-se a ruptura com a idade mítico-mágica, invertendo-se a significação da origem e, correlativamente, a relação da divindade com o mundo. Ora, as antigas divindades permaneciam no interior do mundo visível, porém sem poder atuar sobre algum de seus setores ou sobre a totalidade das coisas. Já o Deus criador, exterior à sua criação, sobre ela exerce influência permanente, controlando o curso do mundo. Mas não se trata de uma intervenção direta sobre o universo, uma vez que se trata de um Deus que se afirma por sua ausência, "através do encontro entre a ordem das razões e a ordem das coisas". A dinâmica de necessidade interna que rege o movimento do mundo atesta a ação do Deus criador, cuja presença não se realiza no âmbito da natureza, mas apenas em relação a si mesmo. Aqui é possível observar o deísmo característico do Iluminismo ou Filosofia da Ilustração do século XVIII. Tal deísmo é representado por pensadores como Locke, Rousseau e Voltaire, dentre outros, os quais afirmam a existência de um Deus único, transcendente, criador do mundo,

\footnotetext{
${ }^{10}$ Em Sobre a questão judaica, Marx (1989) considera que o Estado ateu ou democrático não necessita da religião para a sua consumação política, podendo relegá-la para o domínio da sociedade civil. Ele "pode dispensar a religião porque a base humana da religião realiza-se nele de maneira profana" (MARX, 1989, p. 49). Todavia, o filósofo reconhece a possibilidade de convivência entre o moderno Estado soberano e o homem religioso. Para ele, a emancipação política do homem religioso em geral é a própria emancipação do Estado em relação à religião em geral, isto é, o homem emancipa-se politicamente da religião ao bani-la da vida da comunidade (ou do Estado) para a esfera dos interesses privados, o domínio da sociedade civil. Somente ao libertar-se da religião de Estado, desenvolvendo-se plenamente como Estado político, é que o Estado apresenta-se como terreno profícuo para a existência da religião em suas várias especificidades. Dessa forma, a emancipação política da religião supõe as oposições religiosas em vez de suprimi-las, ao contrário do que pensara Bauer: "a emancipação política não abole, nem sequer procura abolir, a religiosidade real do homem" (MARX, 1989, p.48). Isso significa que o Estado pode se emancipar da religião, tornando-se um Estado livre ou laico, sem que a imensa maioria dos indivíduos que o compõe deixe de ser religiosa. "A emancipação do Estado a respeito da religião não é a emancipação do homem real quanto à religião" (MARX, 1989, p. 53), pois no moderno Estado laico, também chamado democrático ou real, a religiosidade do homem permanece, ainda que relegada ao plano privado, e já não se trata de uma religião privilegiada. Anteriormente a Marx, Rousseau (2000) já propalava a necessidade de se criar uma terceira religião, além daquela dos homens e dos padres. Trata-se da religião civil que, diante da impossibilidade de haver uma religião nacional exclusiva, não tolera a intolerância religiosa e nega toda forma de exclusão ou cerceamento entre as diversas expressões religiosas. Pois para o Estado e o soberano não importam as opiniões de ordem confessional, desde que os dogmas de cada forma religiosa não sejam contrários aos deveres dos cidadãos e reflitam a tolerância mútua. O papel principal da religião civil é impulsionar os homens a amar os seus deveres de cidadãos. Daí que os dogmas da religião civil, ancorados nos sentimentos de sociabilidade, sem os quais é impossível ser bom cidadão ou súdito fiel, se refiram à moral e aos deveres para com o próximo.
} 
mas negam a providência e qualquer relação de Deus com o mundo, a não ser na sua origem com a definição das leis que regem a natureza. Pois uma vez criado, o mundo basta-se a si mesmo, é um mundo metafisicamente enclausurado nele mesmo, hermético, fechado sobre si. Deus é concebido como o "grande arquiteto" ou relojoeiro, que, depois de fabricar o mundo, deixa-o funcionar segundo o automatismo de suas leis naturais, sem nele intervir ou com ele manter qualquer relação. Trata-se de um deus puramente transcendente e ocioso, que não interfere na dinâmica interna das leis naturais em que o mundo mesmo é arrastado.

A inversão da relação de Deus com o mundo é também atestada pelo tema da revelação. Esta implica uma ruptura entre um antes e um depois, entre a época em que o homem não caminha conforme os mandamentos divinos e a idade da verdade, da revelação da mensagem divina e a consequente conversão do homem. Além disso, o Deus da revelação distingue-se dos espíritos do universo mítico: ele opera num presente, em lugar de ter obrado de uma vez por todas no momento da origem; está separado do mundo do qual é senhor, porém se interessa pelo destino dos homens, o qual engloba e domina. Mas acima de tudo, a diferença principal que a revelação introduz é o fato de o seu conteúdo se impor ao entendimento humano como algo que o sobrepõe infinitamente, mas cujo sentido pode ser penetrado e provado pelo homem em seu interior, isto é, através da sua vida espiritual, que não é senão o mergulho do eu em si mesmo ${ }^{11}$. Noutros termos, a força e a grandeza da mensagem revelada não está em seu enunciado coativo, mas se revela na própria exigência de abdicação das verdades humanas frente àquilo que não podemos compreender senão com o auxílio da fé.

\footnotetext{
${ }^{11}$ Neste sentido, Pierre Manent (1986) levanta uma sugestiva crítica ao pensamento de Gauchet. Questiona a razão pela qual se deveria privilegiar, no caso do cristianismo, a dimensão de interiorização da espiritualidade mais que aquela da exteriorização de Deus.
} 


\section{0 mundo desencantado e os "restos de religião"}

Para Gauchet, com o advento da chamada morte de Deus, o homem não passa a ocupar o lugar da divindade. Pelo contrário, o que tal fenômeno revela aos homens é que eles não são deuses. Desta sorte, o que se tem denominado como "fim da religião" e "morte de Deus" Gauchet entende como o declínio do papel político da religião, de sua função de estruturação das sociedades ${ }^{12}$. Fim da religião não significa, pois, extinção da experiência religiosa. Para o autor em foco, "a saída da religião é a saída da estruturação religiosa das sociedades; [...] a saída da religião não significa o fim das crenças religiosas. Elas mudam de lugar e de função, porém subsistem no interior de um mundo que a religião já não organiza" (GAUCHET, 2005, p. 294). No mundo hodierno, a religião já não exerce o seu papel de estruturação da vida material, social e mental dos indivíduos. O que restam são experiências singulares e sistemas de convicções. O que se observa atualmente é uma religiosidade individual, difusa e amorfa, isto é, que não assume para si as formas das religiões históricas constituídas. Para Gauchet, as razões que favorecem essa individualização da religião são: razões de identidade histórica no seio de uma época de globalização e de mistura de diferentes culturas; razões políticas, que surgem da necessidade de definir os fins coletivos; e, sobretudo, razões antropológicas resultantes da experiência que os indivíduos têm de si mesmos.

\footnotetext{
${ }_{12}$ Willaime (1986, p. 71) contesta essa tese da desvinculação entre o religioso e o político, em que se postula o fim das funções sociais da religião e em que o religioso subsistiria apenas como experiência subjetiva e crença individual. Para esse autor, de um ponto de vista sociológico, tal tese é absolutamente contestável. Isso porque, "se é inegável que assistimos, nas sociedades ocidentais, ao fim do poder da religião sobre a sociedade, isso não significa de modo algum que a religião não exerce mais função na estruturação do espaço social e nas identidades coletivas" (WILLAIME, 1986, p. 71). Trata-se do que Willaime $(1981,1985)$ se propôs a mostrar em escritos anteriores sob o signo do que ele próprio denominou de "fundamento infrapolítico do religioso", expressão mediante a qual esse sociólogo se refere não à organização da sociedade sob a tutela do religioso, no sentido de que o religioso daria alguma forma à institucionalização da sociedade, mas ao papel do religioso na constituição de uma sociedade enquanto espaço simbólico singular. Willaime mostra, pois, que se por um lado a religião não exerce mais função no nível da institucionalização da sociedade (isto é, no nível do complexo de práticas pelas quais uma sociedade continuamente se edifica e se modifica), ela continua a exercer uma função no nível da instituição da sociedade, entendida como ereção de um espaço simbólico, em que os atores sociais têm o sentimento de agir sobre o fundo de uma infraestrutura de sentido que desenha um mesmo mundo. Assim, para Willaime (1986, p. 72), "nada é menos evidente do que essa dissociação do religioso e do político da qual nos fala Gauchet", de modo que "o religioso está longe de se reduzir a uma simples experiência subjetiva e a crenças privadas", inscrevendo-se no espaço social e aí cumprindo funções específicas. Haja vista os exemplos do islã, do catolicismo polonês ou de outras situações nas quais religião e política se encontram estreitamente envolvidas, como é o caso, por exemplo, da França. Willaime refere-se a trabalhos de politólogos e sociólogos, como Guy Michelat e Michet, que, a seus olhos, demonstram o quanto permanece forte a correlação entre grau de integração religiosa no catolicismo e preferência política de direita.
}

Horizonte, Belo Horizonte, v. 15, n. 46, p. 376-411, abr./jun. 2017 - ISSN 2175-5841 
Face ao enfraquecimento da função social da religião, Gauchet vê se elevar a função subjetiva da experiência religiosa. De fato, ao extinguir-se sua função social, a religião como sistema, instituição e discurso desaparece. Mas ao passo que o papel da religião se enfraquece na esfera social, ele angaria forças no plano da experiência individual. Noutros termos, extinta a sua função social, a religião conserva ou adquire uma função subjetiva. Como bem esclarece Fortin-Melkevik (1992, p. 80), “o que assume daí em diante uma função subjetiva não é a religião como instituição, mas sim a experiência individual de ordem religiosa que se poderá denominar indiferentemente experiência estética, experiência de si etc.”. O que outrora chamávamos de experiência religiosa seria uma espécie de estrutura antropológica fundamental, um esquema a priori que se configura como a própria “condição de possibilidade trans-histórica" a partir da qual a religião enquanto instituição encontrou fundamento. Deste modo, para além da substituição de funções, Gauchet se detém sobre "a faculdade de uma experiência de tipo religioso para os indivíduos, que estaria enraizada antropologicamente, como um 'núcleo último de religiosidade potencial, lógico e psicológico ao mesmo tempo', [...] como uma espécie de resto antropológico irredutível” (FORTIN-MELKEVIK, 1992, p. 77-78).

Mas embora seja a sua condição de possibilidade, essa experiência subjetiva não necessariamente se vincula à esfera da religião ou se projeta sob a forma de conteúdo religioso. Ela pode funcionar por si mesma, no vazio, isto é, desvinculada de qualquer conteúdo doutrinário fixado por alguma instituição religiosa. Noutros termos, ela pode vir a se manifestar em outros domínios que não o da religião. Segundo Gauchet, o que hoje se observa é que tal experiência se insere no plano do sentimento estético e das práticas do conhecimento de si. É neste sentido que o desaparecimento da função organizadora da religião não implica um declínio do religioso. Para Gauchet, é possível uma saída total da religião sem que o religioso deixe de falar aos indivíduos. O religioso pode subsistir sem religião, isto é, sem atadura a uma tradição ou doutrina religiosa. Isto porque as religiões se apoiam nesse núcleo antropológico que não tem razão para desaparecer. 
Independentemente de qualquer conteúdo dogmático instituído, o substrato subjetivo irredutível que deu origem ao fenômeno da religião permanece, porém se reveste com outra roupagem que não a da instituição religiosa.

Com efeito, mediante a expressão "restos de religião”, Gauchet afirma a permanência, na nossa sociedade contemporânea, de alguns traços religiosos que nos situam numa parcial continuidade com o tempo da religião. Trata-se de "pontos de comunicação entre a ordem de nossa experiência íntima e o que foi a experiência explícita do Outro" (GAUCHET, 1985, p. 293).

O primeiro resto de religião identificado pelo autor se apresenta sob a forma de um sentimento de dualidade de aspecto com relação à realidade. Refere-se à persistência, na esfera cognitiva, do esquema-fonte que ordenava o mundo da religião e que divide a realidade em duas instâncias, a sensível e a suprassensível; ou, numa terminologia platônica, em o mundo das aparências e o mundo inteligível. Segundo Gauchet, é possível perceber este "polo místico” do ilimitadoindiferenciado operando mesmo na ciência moderna, mais precisamente em sua face de conhecimento indireto. Ora, é certo que a ciência postula um conhecimento objetivo dos fenômenos. Entretanto, ela “desqualifica simultaneamente a visão imediata que se pode tomar pelos sentidos em benefício de uma investigação das verdadeiras propriedades das coisas, que ela situa no invisível” (GAUCHET, 1985, p. 295).

Mas dizer que essa divisão permanece subjacente ao pensamento humano não implica afirmar uma remissão a um princípio exterior, o qual, por sua vez, seria o polo organizacional e ordenador do mundo visível. Tal impossibilidade reside no fato de que se trata "de uma divisão das coisas [...], do mundo tal como ele se dá, tomado do interior dele mesmo" (GAUCHET, 1985, p. 294), e não desde uma separação vinda de alhures. Não se trata, portanto, da permanência do sistema que estruturava as sociedades de outrora, e sim daquilo que constituía a sua condição de possibilidade, isto é, o esquema mental a ele subjacente. 
O segundo resto de religião é identificado com o que o autor denomina como experiência estética ou apreensão imaginária do real. Aqui, já não se trata de inteligir a natureza ou a essência das coisas, mas do modo como apreendemos, através da imaginação, o aspecto fenomênico do mundo. Ora, para Gauchet, nossa relação com o real não é apenas recebimento de dados através da sensibilidade e organização destes pela faculdade do entendimento. Ela também passa, necessariamente, pelo plano imaginário. É por ele articulada. Por essa razão, nossa percepção da realidade é habitada pela virtualidade de uma experiência estética, que nos apresenta o mundo como outro, como mistério a ser desvendado.

Com efeito, o mundo torna-se outro a si mesmo porque os deuses deixaram de significar sua alteridade. Ora, a apreensão imaginária do real constituía o suporte antropológico da atividade religiosa. Assim, no tempo da religião o mundo era imaginado sob a regência de uma alteridade exógena. Com o declínio dos deuses, a exterioridade que o governava de fora é subsumida em seu interior. Sem apontar para uma ordem externa que lhe confira sentido, o mundo passa a ser concebido como metafisicamente fechado sobre si ao mesmo tempo que ilimitado fisicamente. Suas leis internas e inerentes apresentam-se como enigma a ser decifrado pela razão autônoma.

Neste contexto, a experiência estética, que antes era apenas um meio para se alcançar o sagrado ${ }^{13}$, desvincula-se dos conteúdos religiosos que norteavam o seu funcionamento, e passa a ser um fim em si mesma. Noutros termos, livre dos conteúdos religiosos que a canalizavam rumo ao sagrado, a apreensão imaginária do real adquire autonomia, passa a funcionar por si mesma, e já não aponta para algo exterior a ela, senão para si mesma. A exploração psicológica de si através da arte passa a refletir uma experiência de tipo religioso - uma experiência do sagrado

\footnotetext{
${ }^{13}$ Gauchet (1985, p. 297) entende o sagrado como "a presença da ausência", "a manifestação sensível e tangível daquilo que normalmente se furta aos sentidos e se subtrai à apreensão humana", ou ainda, a "presença do divino no mundo", a "proximidade fraturante do invisível em meio ao visível". Tendo surgido na virada capital da história religiosa da humanidade que marca a emergência do Estado, o termo sagrado apresenta-se, aos olhos de Gauchet, como uma categoria própria do passado religioso. Ele perde, assim, a sua legitimidade no atual contexto de saída da religião. Isso significa que, no nosso mundo desencantado, é um contrassenso pretender aplicar a categoria de sagrado às formas do religioso que se apresentam no mundo hodierno no intuito de identificá-las como tais, isto é, como sagradas.
} 
- que se desconhece enquanto tal. Isso porque, com o advento do cristianismo, o sagrado situado alhures passa a ter uma transcendência "relativa”, podendo ser encontrado no interior de si. Daí que a arte seja por Gauchet identificada como “a continuação do sagrado por outros meios” (GAUCHET, 1985, p. 297).

A última forma de experiência pela qual nos inscrevemos em continuidade com o homem da religião é a experiência do problema que somos para nós mesmos. Com efeito, com a saída do sistema da alteridade absoluta do fundamento, o problema da assunção de si se apresenta sob sua dupla face: necessidade de justificação de si e tentação de negar-se a si mesmo. Trata-se da contradição constituinte do ser-sujeito, que se apresenta oscilante entre negação e afirmação de si mesmo, entre a perda de si e o encontro consigo mesmo numa plena e necessária identidade, enfim, entre o ser e o não ser.

A essa questão, que se forma no interior de nós mesmos, as religiões tentam oferecer uma resposta cabal. E uma vez que os sistemas espirituais dão por solucionado o que fora deles vivemos como problemático, o homem contemporâneo se encontra de tal modo fascinado pela memória recapitulada do mundo das crenças que procura reconstituir as formas e os tempos religiosos de outrora. Pois quando a religião finaliza sua trajetória, isto é, quando se esgota sua função social, ela abandona o homem a si mesmo. Noutros termos, com a queda da exterioridade religiosa, o homem fica entregue às próprias forças e questionamentos que faz a si. E quanto a estes, há que elaborar suas próprias respostas. A saída do "tempo da religião" se correlaciona, portanto, ao advento de uma época individualista. E como afirma Gauchet (1985, p. 300), "quanto mais individualização, também mais problema de si, portanto, mais interesse potencial pelos tempos em que se sabia o que fazer com esta temível incerteza que nos atravessa”. Ora, fora do sistema da alteridade absoluta do fundamento, os indivíduos terão que procurar em si e a partir de si o sentido das suas existências e das suas ações. Sem se remeter a uma força extrínseca a ele mesmo, o homem terá 
de responder à pergunta sobre si - ou seja, terá que dar as razões do próprio ser que agora se ergue com agudeza em seu interior.

Neste sentido, o dispositivo religioso das sociedades de outrora é tanto uma neutralização da cisão constitutiva da sociedade, tal como explicitamos anteriormente, como uma neutralização em relação à pergunta que o homem levanta sobre si mesmo. Ora, se o sentido provém de uma alteridade absoluta, as razões da existência ou do ser-aí-no-mundo já estão dadas de antemão. A pergunta sobre si, que se aflora no interior do sujeito, encontra numa exterioridade a sua resposta. O mundo visível é regido pela força das implacáveis moiras. Não é compreendido sob a lógica da contingência, mas arrastado na dinâmica da necessidade. A posição que os homens ocupam no seio da sociedade, assim como a função exercida, já estão predeterminadas. Assim, não há espaço para a assunção de si até o outro de si. O homem se autocompreende enquanto tal na medida em que se encontra referido ao todo social. Trata-se de um sistema de "necessidade" e de "a-subjetivação" de si, no qual o individual se dilui no coletivo e é por este determinado.

Neste sistema de economia simbólica da dívida com um passado fundador, as causas dos grandes acontecimentos, assim como toda ação transformadora sobre a sociedade e a cultura, não são atribuídas ao homem, mas aos deuses, heróis e ancestrais míticos. Estes teriam vivido no passado fundador, do qual o tempo atual é herdeiro e cópia, e cujos feitos os homens devem incessantemente repetir e atualizar através dos ritos. É, pois, neste sentido que a invenção da agricultura recebe a significação de herança dos deuses, e não criação humana.

Mas ao passo que a problemática de si se intensifica com o declínio da religião, também cresce a dificuldade em identificar a solução. Disso resultam as conversões sem adesão íntima, ou seja, momentâneas, passageiras, não duradouras. Daí também os indivíduos da era pós-religião fazerem “colagens” sincréticas e instáveis, combinando fragmentos de símbolos, ritos e doutrinas 
provenientes de diferentes e diversas fontes religiosas, numa simbiose em que se pode encontrar esoterismo, ocultismo, filosofia, ciência, gnose e expressões religiosas de cunho oriental. Todavia, adverte-nos Gauchet que a emergência desse pluralismo religioso, que povoa o cenário ocidental sob a forma de "novos movimentos religiosos" e de pertinentes tentativas de reconstituição da estrutura religiosa das sociedades do passado, não implica um retorno do sagrado, como querem alguns teóricos. Antes, significa a própria saída da "era da religião", um desencantamento do mundo que passa a se tornar pleno em lugares que antes só chegava de forma remota.

\section{Conclusão}

A tese de Gauchet, enfeixada sob o signo do desencantamento do mundo ou saída da religião, é forjada a partir de uma dupla perspectiva. Numa visão macroscópica, é tecida uma análise histórica de longo alcance, visando compreender as estruturas das diferentes sociedades, antigas e modernas, no que diz respeito a uma possível relação de tais organizações sociais com a própria esfera religiosa. Já numa outra perspectiva, mais microscópica, Gauchet procura fornecer uma visão histórico-filosófica do presente, procurando compreender as transformações pelas quais atravessam tanto a religião quanto as chamadas sociedades modernas e contemporâneas.

Mediante uma metodologia em que se articulam teses filosóficas e análises históricas, o filósofo francês procura compreender o que pode subsistir de religião além da era das religiões. Como bem sublinha Mongin (1985, p. 34), o próprio da análise levada a termo por Marcel Gauchet é o seu distanciamento da "atual compartimentação das disciplinas e da burocratização intelectual que a acompanha”. Todavia, na própria medida em que reivindica a si uma integração dos saberes filosóficos, teológicos, históricos - e poder-se-ia acrescentar, 
sociológicos e antropológicos ${ }^{14}$-, o pensamento de Marcel Gauchet, em seu projeto ambicioso, expõe-se à crítica como nenhum outro (WILLAIME, 1986, p. 68).

De fato, Gauchet se dedica a um gesto de pensamento que visa a "recomposição de uma compreensão religiosa do elemento mais antirreligioso que possa existir, isto é, a História” (GAUCHET, 2004, p. 118). Debruçando-se sobre a questão da origem da religião nas sociedades sem escrita, Gauchet entende que a religião exerce um papel preponderante e essencial na edificação estrutural e organizacional de tais sociedades, à medida que se ergue como o ato originário mediante o qual o próprio corpo social veio a se constituir. A seu ver, essas sociedades são marcadas, em sua própria estrutura ontológica, tanto pelo culto a um passado puro e heteronômico quanto por uma escolha a favor do sobrenatural e contra o poder encerrado na figura de um só indivíduo ou de vários. Tais sociedades fundam-se, pois, numa divisão de origem e caráter religiosos e mediante a qual se supõe a existência de uma dimensão absoluta, exclusivamente delimitada pela presença de um Totalmente Outro, o heterônomo sagrado que, enquanto tal, isto é, à medida que se apresenta como separado e transcendente, rege a totalidade do tecido social.

As tramas enredadas pelo advento do Estado nas altas civilizações da antiguidade constituem o segundo momento da análise histórica levada a termo por Gauchet. Nessa etapa, segundo a perspectiva gauchetiana, a emergência histórica do Estado desencadeia uma notável "metamorfose do divino" que, por sua vez, transforma completamente as antigas formas de se ordenar o mundo. Em outras palavras, o lugar ocupado pelo divino é então modificado: outrora concebido sob o signo de um absoluto distante e apartado, ele passa a ser corporificado no âmbito sociopolítico. Sua transcendência é como que imanentizada na estrutura social. Deslocando o divino de seu locus original, o florescimento do Estado abre,

\footnotetext{
14 Daí o fato de o autor de $O$ desencantamento do mundo ter definido o seu projeto sob o signo de uma "antropossociologia transcendental" (GAUCHET, 1985, p. 239). Neste sentido, com justa razão acrescenta ainda Willaime (1986, p. 68-69) que, no caso do modo de pensar gauchetiano, "estamos longe das aproximações reducionistas do fenômeno religioso e das interpretações que concluem um declínio inelutável do religioso como dimensão singular da experiência humana".
} 
pois, uma fenda no mundo humano, dividindo a história em duas partes. Assistimos, assim, à eclosão do chamado período axial, marcado pela emergência de grandes figuras religiosas ou reformadores espirituais, tais como Buda, Lao-Tsé, Confúcio, os profetas israelitas e os filósofos gregos.

Por fim, Gauchet se interroga acerca do que julga poder identificar como as raízes cristãs do movimento da modernidade. Desse modo, a análise gauchetiana postula a tese segundo a qual o cristianismo é "a religião da saída da religião", ou seja, a religião que cumpre a realização do movimento outrora iniciado pelo advento do Estado, levando à definitiva transmutação da antiga ordem heteronômica por uma ordem autonômica. Como ápice desse longo processo, o cristianismo engendraria o desfecho de toda essa transmutação histórico-social, abrindo o mundo humano da cultura para o aparecimento de toda sorte de experiências ditas espirituais e religiosas, multifacetadas e pluriformes, as quais Gauchet compreende, no entanto, sob o signo de "restos" ou "vestígios” da religião. O que se descortina aí é um mundo humano marcado não mais pela religião, mas por vivências que, a despeito de serem nomeadas como religiosas, espiritualistas ou algo similar, se erguem como novos modos de ser do homem, agora situado num mundo pós-religião ${ }^{15}$.

Por conseguinte, o que os tempos atuais testemunham não é nem um processo de secularização nem um movimento de laicização, "como se tratasse simplesmente de restituir os homens a si mesmos" (GAUCHET, 2004, p. 117). O que ocorre, e que é denominado por Gauchet como saída da religião, é o fim do papel social da religião. Isso equivale a dizer que "a modernidade mudou radicalmente as modalidades institucionais do religioso, mas não a crença religiosa

\footnotetext{
${ }^{15}$ No que diz respeito ao fenômeno denominado por Gauchet como pós-religião, caberia uma série de questionamentos. Num matiz de tonalidade sociológica, por exemplo, conviria perguntar, tendo-se em vista a peculiaridade da realidade brasileira, se tal fenômeno não se situa mais fortemente em setores médios e urbanizados em nosso território nacional. Mais ainda, cumpriria questionar se o fenômeno da pós-religião não se contextualiza mais propriamente na realidade sociocultural do hemisfério norte e em países industrializados. Até que ponto, pois, a abrangência do fenômeno identificado por Gauchet estende-se a toda amplitude da cidade dos homens? Por outro lado, poder-se-ia questionar, como fez Manent em discussão com Marcel Gauchet (1986), se a análise histórica proposta por Gauchet não sugere uma versão demasiadamente otimista das relações entre religião e modernidade. Se essa última, longe de apenas ter tornado possível as religiões da transcendência, não vai se instituir exatamente contra a religião.
} 
propriamente dita", de modo que "os motivos que dão origem à religião do ponto de vista coletivo desapareceram, mas os que lhe dão nascimento do ponto de vista da experiência individual subsistem" (GAUCHET, 2004, p. 129). Numa palavra, "o espírito moderno triunfou, mas sem fazer desaparecer o espírito de fé" (GAUCHET, p. 153-154). Desde então, a dimensão religiosa é constrangida a centrar-se sobre a convicção individual. Segundo Gauchet (2004, p. 162), "sua fórmula poderia se enunciar: o religioso (ou seus sucedâneos) ao serviço do indivíduo". Afirmar o declínio do papel social da religião não equivale, pois, a preconizar a erradicação das crenças religiosas. De fato, para Gauchet, não há razão alguma para que a fé venha a desaparecer no horizonte histórico previsível. As crenças religiosas podem subsistir, sem que isso implique a estruturação religiosa do vínculo social. Proclamar, pois, um mundo desencantado significa dizer que, apesar de uma eventual maioria de crentes, e até mesmo uma quase unanimidade em matéria de fé, a cidade dos homens não mais se organiza religiosamente. Segundo Gauchet, no hodierno mundo desencantado a religião pode até vir a exercer uma influência política de modo eventual, mas não um papel de estruturação política.

Por outro lado, as diversas manifestações religiosas a que atualmente assistimos não constituem o sinal inequívoco de um "retorno do sagrado" em sentido estrito, de uma "revanche dos deuses" ou de um novo "rumor de anjos", como Peter Berger chegou a proclamar. De fato, "não basta que alguns, e mesmo um grande número, acreditem no mundo encantado, para que o mundo humano se reencante, para que se recomponha um entendimento religioso da natureza da comunidade política”, diz Gauchet (2004, p. 161). Não há, pois, aos olhos gauchetianos, reestruturação sacral do universo humano. Isso porque "a intensificação da crença não é a remodelagem do espaço humano segundo o antigo molde sacral" (GAUCHET, 2004, p. 145). No entendimento desse filósofo, há uma distância, a ser levada em consideração, entre a fé reivindicada pelos indivíduos e sua efetiva capacidade de normatizar os comportamentos coletivos. Assim, "reclamar-se explicitamente da Igreja é uma coisa, esperar que ela nos forneça o quadro cotidiano de nossa conduta é outra coisa" (GAUCHET, 2004, p. 149). Desse 
modo, o problema que se ergue não é o relativo a se as pessoas continuam ou não a crer em Deus, mas é o de saber qual é o lugar que essa crença ocupa, bem como o papel que ela desempenha, no mundo social habitado por esses indivíduos.

O que se observa é, pois, uma "metástase da era do sagrado" (GAUCHET, 2004, p. 119), ou seja, uma dinâmica em que "o que outrora se passava pela alteridade religiosa se converte, metaboliza-se", de modo que "não cessamos de reabsorver a alteridade religiosa em nós mesmos por um movimento contínuo", dissuadindo-nos “a nos tornar estranhos a nós mesmos” (GAUCHET, 2004, p. 117118). Desse modo, aquilo que Gauchet denomina de desencantamento do mundo ou saída da religião está longe de ser um processo linear e simples, mas, ao contrário, se impõe como um movimento inexorável e irreversível, inviabilizando qualquer tentativa de retorno absoluto aos fundamentos incondicionais, tal como preconizado pelos fundamentalismos religiosos (GAUCHET, 1985, p. I-XXIII; 2004, p. 165-177).

Para Gauchet, o aspecto peculiar do movimento próprio à modernidade, enquanto movimento de saída da organização religiosa do mundo, consiste em deixar a questão religiosa em aberto, e isso num sentido bastante preciso. "Seu processo fundamental”, explica Gauchet (2004, p. 154), “é um processo de dissociação das duas ordens de realidade tradicionalmente ligadas, céu e terra, visível e invisível”. A favor de tal dissociação, opera-se a constituição prática de uma ordem da autonomia humana, que deixa totalmente aberta, todavia, a questão dos fins e do sentido último do mundo humano. Por conseguinte, a noção de autonomia não equivale à afirmação de que a sociedade esteja em posse, de uma vez por todas, de seu sentido. Ao contrário, ela remete à ideia de que a cidade dos homens passou a se articular em torno da deliberação sobre si mesma. Daí também que a saída da estruturação religiosa do mundo não implique o fim das crenças religiosas. Antes, essa nova realidade ou "essa definição explicitamente extrarreligiosa da cidade dos homens", tal como a denomina o próprio Gauchet 
(2004, p. 105), impõe a necessidade de um novo instrumentário terminológicoconceptual com vistas à compreensão de seu significado ${ }^{16}$.

\section{REFERÊNCIAS}

ABEL, Olivier et al. Modernité et religions. Débat entre Olivier Abel, Jean Baubérot, Marcel Gauchet et Olivier Mongin. Autres Temps: cahiers d'étique sociale et politique, Paris, n. 62, p. 51-60, 1999.

BARBOSA, Wilmar do Valle; LOTT, Henrique Marques. "O religioso após a religião": um debate entre Marcel Gauchet e Luc Ferry. Horizonte, Belo Horizonte, v. 8, n. 19, p. 71100, out.-dez. 2010.

BRETON, Stanislas. La religion s'efface-t-elle de nos sociétés modernes? Libres propos sur Le Désenchantement du monde de Marcel Gauchet. Revue des Sciences

Philosophiques et Théologiques, Paris, v. 69, n. 4, p. 563-576, oct. 1985.

BRIEY, Laurent de. Démocratie, religion et pluralisme: de Tocqueville à Gauchet et retour. Revue Philosophique de Louvain, Louvain, v. 104, n. 4, p. 741-761, 2006.

CLASTRES, Pierre. La société contre l’État. Paris: Éditions de Minuit, 1974.

COLIN, Pierre; MONGIN, Olivier (Dir.). Un monde désenchanté? Débat avec Marcel Gauchet sur "Le désenchantement du monde". Paris: Cerf, 1988.

DONNADIEU, Gérard. Genealogia da religião: ensaio de leitura sistêmica de Marcel Gauchet. Aplicação à situação atual do mundo. Cadernos IHU Ideias, São Leopoldo, ano 3, n. 44, p. 1-21, 2005.

FERRY, Luc; GAUCHET, Marcel. Le religieux après la religion. Paris: Grasset, 2004.

FORTIN-MELKEVIK, Anne. A exclusão recíproca da modernidade e da religião nos pensadores contemporâneos: Jürgen Habermas e Marcel Gauchet. Concilium, Petrópolis, v. 6, n. 244, p. 70-82, 1992.

GAUCHET, Marcel. A dívida do sentido e as raízes do Estado: política da religião primitiva. In: CLASTRES, Pierre et al. Guerra, religião, poder. Lisboa, 1977. p. 49-89.

GAUCHET, Marcel. La démocratie contre elle-même. Paris: Galimard, 2004.

GAUCHET, Marcel. La religion dans la démocratie: parcours de la laicité. Paris: Gallimard, 1998.

\footnotetext{
${ }^{16}$ A exigência desse novo aparato terminológico-conceptual foi preconizada por Gauchet na ocasião de um debate com outro filósofo francês, Luc Ferry, em janeiro de 1999, realizado a convite do Collège de Philosophie de Paris (FERRY; GAUCHET, 2004). A propósito desse debate, ver: Barbosa e Lott (2010); Lott (2014, p. 213-232).
} 
GAUCHET, Marcel. Le désenchantement du monde: une histoire politique de la religion. Paris: Gallimard, 1985.

GAUCHET, Marcel. Lo religioso hoy: conversación con Esteban Molina. In: GAUCHET, Marcel. El desencantamiento del mundo: una historia política de la religión. Madrid: Trotta, 2005. p. 293-302.

GAUCHET, Marcel. Un monde désenchanté? Paris: Les Éditions de L’Atelier, 2004.

GAUCHET, Marcel; MANENT, Pierre. Comment traiter de la religion? Discussion entre Marcel Gauchet et Pierre Manent. Esprit, Paris, n. 5, p. 201-212, 1986.

HERVIEU-LÉGER, Danièle. O peregrino e o convertido: a religião em movimento. Petrópolis: Vozes, 2008.

HERVIEU-LÉGER, Danièle. Società e atteggiamenti religiosi in Francia. In: HERVIEULÉGER, Danièle et al. La religione degli europei. Torino: Fondazione Giovanni Agnelli, 1992. p. 155-216.

LOTT, Henrique Marques. Compreensões sobre o momento contemporâneo da saída da religião e sobre a condição atual da laicidade: entrevistas com pesquisadores franceses. Horizonte, Belo Horizonte, v. 14, n. 41, p. 185-199, jan.-mar. 2016.

LOTT, Henrique Marques. O limiar entre religião e democracia na obra de Marcel Gauchet. Plura, v. 5, n. 1, p. 19-33, 2014.

LOTT, Henrique Marques. Religião, política e democracia: a sociedade desencantada de Marcel Gauchet. São Paulo: Fonte Editorial, 2016.

MAGNELLI, André. O desencantamento do mundo e o advento da autonomia: 30 anos da história política da religião de Marcel Gauchet. Coletânea, Rio de Janeiro, ano 14, v. 27, p. 44-71, jan.-jun. 2015.

MARX, Karl. Sobre a questão judaica. Lisboa: Edições 70, 1989.

MONGIN, Olivier. Quand la religion s'éclipse. Esprit, Paris, n. 10, p. 34-49, 1985.

MONTEIL, Pierre-Olivier. La grâce et le désordre. Entretiens sur la modernité et le protestantisme avec Jean-Paul Willaime, Jean Baubérot, Marcel Gauchet, Pierre Manent, Marc Augé, Olivier Mongin, Olivier Abel, Pierre Gisel et Pierre Bühler. Genève: Labor et Fides, 1998.

PIERUCCI, Antônio Flávio. O desencantamento do mundo: todos os passos do conceito em Max Weber. São Paulo: Editora 34, 2003.

ROSSEAU, Jean-Jacques. Do contrato social: princípios do direito político. Bauru: EDIPRO, 2000. 
STEIL, Carlos Alberto. Para ler Gauchet. Religião e Sociedade, Rio de Janeiro, v. 16, n. 3, p. 24-49, mai. 1994.

TERRAY, Emmanuel. Sur Le Désenchantement du Monde de Marcel Gauchet. Le Genre Humain, Paris, n. 23, p. 109-128, 1991.

VALADIER, Paul. Sur la religion: un échange avec Paul Valadier. In: GAUCHET, Marcel. La démocratie contre elle-même. Paris: Galimard, 2004. p. 67-90.

VAZ, Henrique Cláudio de Lima. Escritos de filosofia VI: ontologia e história. São Paulo: Loyola, 2001.

WILLAIME, Jean-Paul. À propos du "Désenchantement du monde" de Marcel Gauchet. Autres Temps: les cahiers du christianisme social, Paris, n. 9, p. 68-75, 1986.

WILLAIME, Jean-Paul. De la fonction infrapolitique du religieux. The Annual Review of the Social Sciences of Religion, v. 5, p. 167-186, 1981.

WILLAIME, Jean-Paul. La religion civile à la française. Autres Temps: les cahiers du christianisme social, Paris, n. 6, p. 10-37, 1985. 